\title{
10. AEOLIAN TRANSPORT OF DUST OFF WESTERN AUSTRALIA ${ }^{1}$
}

\author{
J. R. Heirtzler, Woods Hole Oceanographic Institution, Woods Hole, Massachusetts
}

\section{EFFECT OF OFFSHORE WINDS}

Because of its latitude and north-south coastline, the western coast of Australia experiences appreciable winds blowing offshore. If the continental shelf was narrower, these winds could be expected to produce upwelling of cold subsurface waters with concomitant biologic enrichment of surface waters, as occurs off Peru, South Africa, northwest Africa, the northwestern United States, and elsewhere. While some upwelling has been reported off northwestern Australia (Wyrtki, 1962; Rochford, 1962), it is apparently not appreciable along the remainder of the western continental margin of that country. Thus, the sediments off that margin should not show the strong biogenetic component characteristic of upwelling regions.

The frequent offshore winds do, however, blow over desert terrain, and may be expected to carry appreciable aeolian material to sea. Similar situations exist in other localities (Arrhenius, 1959), most notably in the Atlantic off North Africa where airborne particulate matter has been traced across the entire ocean to Barbados (Prospero and Colson, 1972). Such airborne particulate matter can be expected to be a significant contributor to the inorganic suspended matter in the surface waters and is likely to have been a major contributor to the sediments of the eastern Indian Ocean since Australia separated from Antarctica and moved to more northerly latitudes in the Eocene.

Although dust storms and dust haze are common occurrences in western Australia, their frequency and nature have not been studied by the Commonwealth Bureau of Meteorology or the Australian Atomic Energy Commission. ERTS high-resolution satellite photographs of three principal Australian dune areas have been studied by E. D. McKee (personal communication, 1973), but he reports being unable to identify dust haze or storms in the satellite images. Onboard Glomar Challenger cloud cover was directly monitored from the NOAA satellite, but resolution did not permit distinguishing dust clouds here, either.

Daily weather maps were, however, received on Glomar Challenger by facsimile recorder from the Australian mainland. The isobars on these maps were constructed from reports of western Australian land stations with reports from an occasional ship from the eastern Indian Ocean being included. From these, one can deduce near-surface wind flow. They provide less information about tropospheric winds which may be important in long-range aeolian transport.

'Woods Hole Oceanographic Institution Contribution No. 3200.

\section{AIR-PARTICLE COUNT}

An air-particle counter was also on Glomar Challenger and its results were sent regularly to W. P. Elliott of Oregon State University. The meteorologist onboard, M. C. Fields, took readings with this instrument on a 4- to 8-hour basis on Leg 27. While this instrument could give no information about the nature of the particles, it did give the number per cubic centimeter. Although previous count records were not available, at Site 259 it became immediately apparent that the number density reached anomalously high values (over $1000 / \mathrm{cc}$ ) in that area. Similar values were also noted while at Site 263 where visibility was noticeably limited by haze. Areas of apparent haze could be observed on the ship's radar at night.

High values of particle count were recorded just prior to arriving in port on 8 December. High values were also found when the ship sailed out of port at the beginning of the cruise, but, at that time, winds were from the stern and it is possible that readings were contaminated by emanations from the ship's stack.

\section{ASSOCIATED METEOROLOGICAL CONDITIONS}

In the three areas where anomalously high relative values of airborne particles were observed, the ship was between Fremantle and Northwest Cape and within 370 $\mathrm{km}$ (200 n.m.) of shore. Occasional high values were reached in other geographic areas and at other times along Leg 27. A high probability of finding high values in this particular zone seems to be established, at least for this time of year.

Examination of meteorological maps showed that a large, well-established barometric high existed in the Great Australian Bight [area] south of Australia, coincident with high particle counts on Sites 259 and 263 (see Figures 1 and 2). The counterclockwise circulation around such highs would carry dust from potential source areas in Western Australia out to sea.

Desert terrain extends right up to the coast just south of Northwest Cape, and the other coastal areas are distinctly arid. A wind from the east with an average speed of $32 \mathrm{~km} / \mathrm{hr}(20 \mathrm{mph})$ would need to blow only 10 hours to transport this material. At Site 259 the wind speed increased from about $16 \mathrm{~km} / \mathrm{hr}(10 \mathrm{mph})$ on 4 November to about $64 \mathrm{~km} / \mathrm{hr}(40 \mathrm{mph})$ on 6 November. The particle count increased from a few hundred/cc to $3000 / \mathrm{cc}$ over the same time interval. Wind directions on the ship varied from southwest to southeast during this time, suggesting that air-transported material may have come by a more circuitous route. The high particle counts observed at the end of the stay at Site 263 and on into Fremantle followed $37-\mathrm{km} / \mathrm{hr}(20 \mathrm{knot})$ winds from 


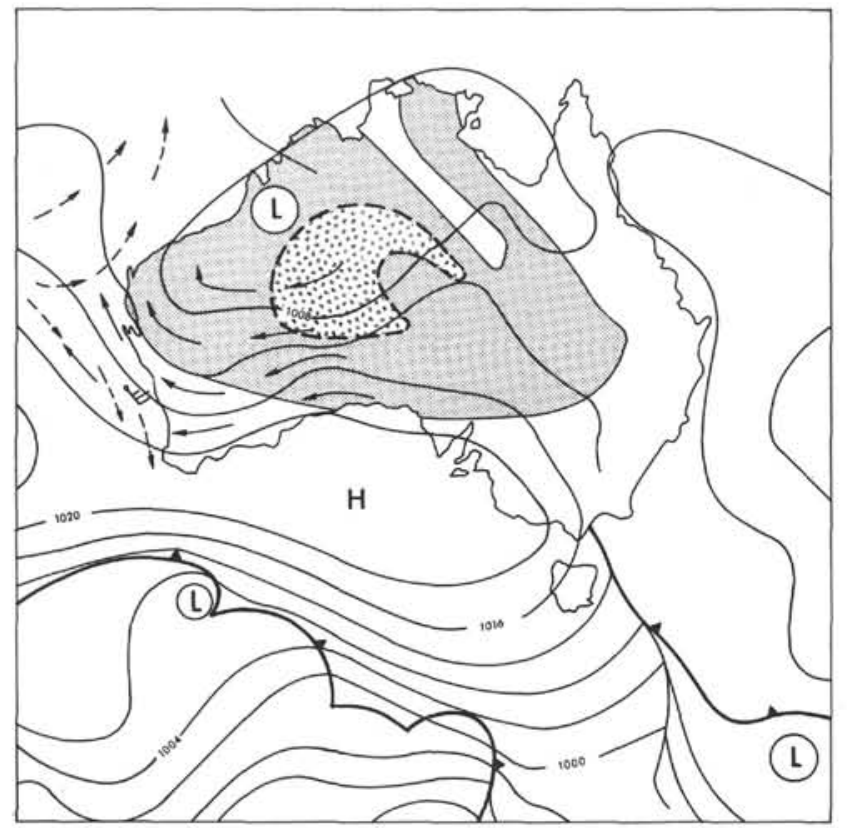

Figure 1. Atmospheric pressure distribution $(\mathrm{mb})$ around Western Australia at $1100 \mathrm{Z}, 6$ November 1972. Solid arrows show wind direction; broken arrows show generalized ocean-current direction (after U.S. Navy, Atlas of Pilot charts, 1966); shaded area shows soil area characterized as desert and table-land types (Spate, 1957); dashed line encloses dune areas (Salisbury, 1957).

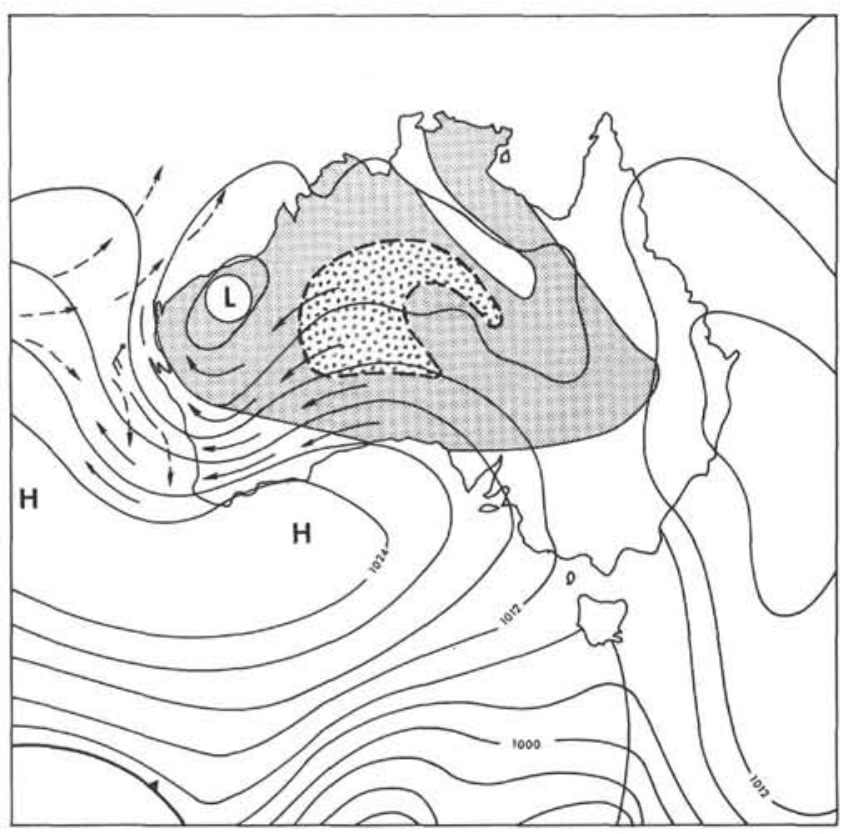

Figure 2. Atmospheric pressure distribution ( $\mathrm{mb}$ ) around Western Australia at 1100 Z, 6 December 1972. Solid arrows show wind direction; broken arrows show generalized ocean-current direction (after U.S. Navy, Atlas of Pilot Charts, 1966); shaded area shows soil area characterized as desert and table-land types (Spate, 1957); dashed line encloses dune areas (Salisbury, 1957). the south to southeast which had persisted for several days.

\section{POSSIBLE ASSOCIATION OF AEOLIAN MATERIAL TO SUSPENDED MATTER}

While it seems likely that a general relationship exists between the aeolian material transported off the western side of the Australian continent and suspended matter in the surface water, there is not likely to be simple one-toone relationship between these two variables at any one place or time.

Figure 3 shows the temporal variability of both total suspended matter and air-particle count. Both time series appear to have a nearly diurnal component. While the biologic component of suspended matter may contribute to a diurnal component of that variable, it is difficult to know what would cause a diurnal component to the air-particle count.

The air-particle count is doubtless related to the immediate past history of winds between the observation point and the aeolian source area. The surfacesuspended sediment is doubtless related to the immediate past history of surface ocean currents in the area and sediment source. The sediment source is just the deposited aeolian material minus that which has settled below the surface or been carried below the surface by turbulent mixing.
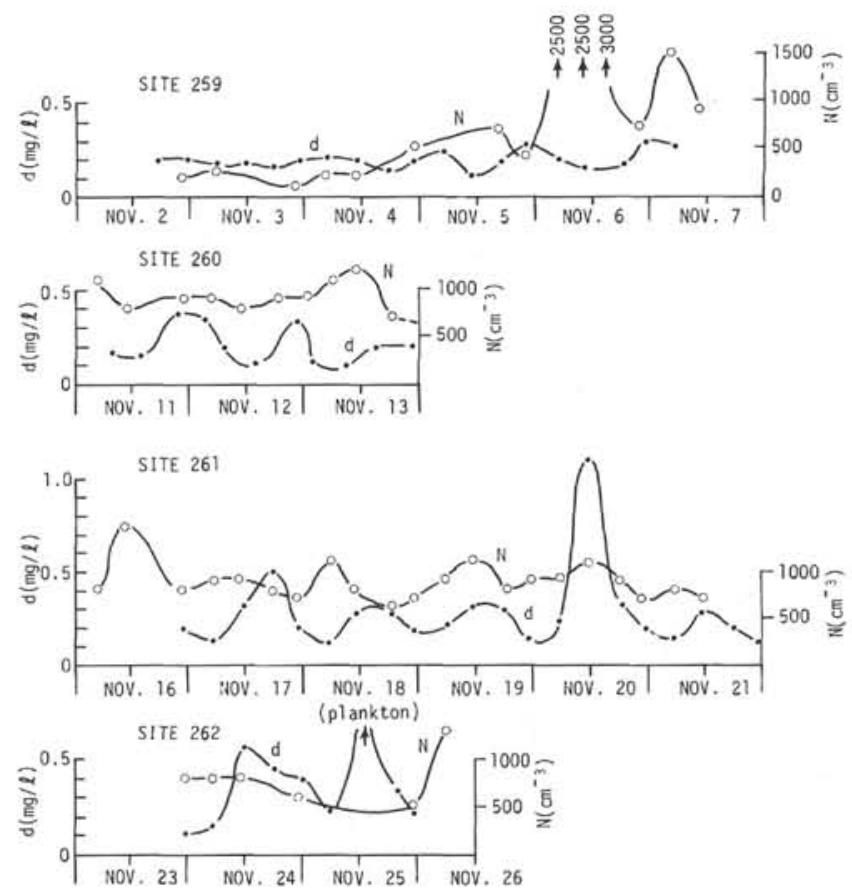

SITE 263

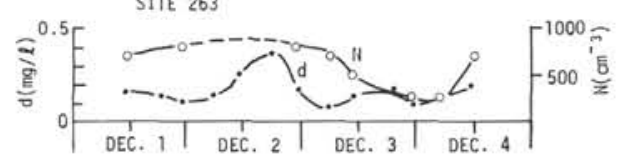

Figure 3. Variation of suspended sediments load (closed circles) and atmospheric particle density (open circles) while on drilling sites. 
Arrhenius (1963) quotes a study of aeolian dust from Illinois showing that air particles are unlikely to have material smaller than one or a few microns or larger than 15 or 20 microns. Aeolian particles in this size range would likely take some time to settle, and thus aeolian material deposited upstream may be expected to play a role in the suspended matter found at any one time and place. Also small ocean currents are likely to be significant in the horizontal mixing and distribution of aeolian suspended sediments.

The aeolian material is doubtless attempting to settle, according to particle size, as it is airborne and carried seaward by the wind. Some sorting must take place in the atmosphere.

One might expect the size-distribution curve of airborne particles to become more peaked towards smaller sizes at greater distances from land. The offshore ocean currents may be north- or south-flowing, varying with the southeast Trade Wind belt (Atlas of Pilot Charts, U.S. Navy, 1966). This mixing is likely to prohibit any north-south sorting of particle size.

The time scale on which measurements were made and the lack of synoptic measurements over local areas preclude detailed interpretation of the air-particle and suspended-sediment observations and their possible interaction, but suggest more fully instrumented experiments that could be carried out.

\section{ACKNOWLEDGMENTS}

The efforts of M. L. Fields in taking XBT's and recording daily weather maps, satellite cloud cover maps, and particle counts are greatly appreciated. W. P. Elliott of Oregon State University kindly permitted use of particle-count data for this leg.

\section{REFERENCES}

Arrhenius, G., 1959. Sedimentation on the ocean floor. In Abelson, P. H. (Ed.), Researches in geochemistry: New York (Wiley), p. 1.

1963. Pelagic sediments. In The sea, vol. 3, Hill, M. N. (Ed.), New York (Interscience), p. 655.

Prospero, J. M. and Colson, T. N., 1972. Vertical and areal distribution of Saharan dust over the western Equatorial North Atlantic Ocean: J. Geophys. Res., v. 77, p. 5255.

Rochford, D. J., 1962. Hydrology of the Indian Ocean II. Surface waters of the southeast Indian Ocean and Arafura Sea in the spring and summer: Australian J. Marine Freshwater Res., v. 13, p. 226.

Salisbury, E. J., 1957. In Encyclopaedia Britannica, v. 2: Chicago (Encyclopaedia Britannica, Inc.), p. 711.

Spate, O. H. K., 1957. In Encyclopaedia Britannica, v. 2: Chicago (Encyclopaedia Britannica, Inc.), p. 706.

U.S. Naval Oceanographic Office, 1972. Atlas of pilot charts of South Pacific and Indian oceans, H. O. Publ. No. 109 3rd Ed.: Washington (U.S. Government Printing Office).

Wyrtki, K., 1962. The upwelling in the region between Java and Australia during the southeast Monsoon: Australian J. Marine Freshwater Res., v. 13, p. 217. 